\title{
二國先生の思い出
}

\section{Professor Ziro Nikuni}

\section{Roy L. Whistler}

Professor Ziro Nikuni and I became acquainted in 1954 when he came to Purdue for a year so that he and I could work together to learn more about the nature of the starch granule. We had a new electron microscope and Professor Nikuni undertook the examination of the interior physical structure of the granule that could be revealed by the $15-20$ angstrom resolution available that time. Professor Nikuni could section a starch granule into more than 100 serial sections and could follow a cavity from beginning to end. In that period we were learning that by slow drying a granule could be case hardened and that as moisture was released from the granule stresses were set up and, like those in a drying mud ball, were sometimes partially relieved by development of cracks or cavities.

Professor Nikuni and I had many interesting research discussions either at the University or over a good meal. Professor Nikuni liked students and was a good friend of the research students and of faculty members, not only those in the Department of Biochemistry but those in the broad reaches of the University.

Following his year stay, we met often in Japan and in other parts of the world. Mrs. Whistler and I continually enjoyed these meetings with Professor and Mrs. Nikuni, and when the occasion arose also with Miss Nikuni. On one occasion Professor Nikuni took me to a very small second floor bar in Tokyo to show me where, as a student, he sometimes stopped with friends and we also had a glass of Suntory. He took me to see Cormorant fishing and showed me where I could stay in a small lovely Japanese hotel. When I received the Japanese Award in Starch he arranged a beautiful trip in the Lakes District with my good friend and former associate Dr. Tamura as guide.

Professor Nikuni was the Official Representative for Japan on the formation of the International Carbohydrate Organization. This participation greatly helped Japan's rise as a recognized research power in world carbohydrate chemistry, enzymology and general carbohydrate biochemistry.

His coming to Purdue was the beginning of a fine relation between Purdue and many excellent Japanese carbohydrate scientists. Among those who came to the University were:

Dr. Susumu Hirase
Kazufumi Yagi
Norito Uchino
Taro Tamura
Mario Suzuki
Susumu Ishiguro
Noboru Ototani
Saburo Inokawa
Tetsuro Ikekawa
Kazuhiko Yamamoto
Akira Hasegawa
Toshio Fukui
Hidetsugu Fuwa

I am sure my memory is incomplete and that I have missed other fine Japanese scientists who came to Purdue because of Professor Nikuni's recommendation or suggestion.

Professor Nikuni was greatly interested in the broad field of carbohydrates and their related enzymology and metabolism. His concern with starch and cereals led the American Association of Cereal Chemists to present him the Alsberg-Schoch Award in 1980. I was pleased to participate in the ceremony and in the celebration afterward with his many friends who gathered for the rejoicing. Following the meeting I took him to see the world center and home of Rotary International in Chicago where I took his picture sitting in the chair used by the International President when he is in residence.

Professor Nikuni was active for a long time 
as a member and an officer in Rotary. We then drove to Lafayette where Mrs. Whistler and I enjoyed talking with him of many events. Thereafter, I saw him on several visits to Japan and corresponded to the time of his death. Professor Nikuni was a great scientist, administrator and humanitarian. My friendship with him is a treasure that I shall always remember.

(米国 purdue 大学)

\section{Memories of Dr. Ziro Nikuni -A Gentle Giant}

David R. Lineback

When Dr. S. Kobayashi informed me of Dr. Nikuni's death, following a telephone call from Dr. K. Kainuma on Nov. 22, there was an immediate sense of a deep loss. While I had known that Dr. Nikuni was critically ill, being too ill for me to visit him during a trip to Japan in August, 1984, there was always the hope that he would be with us for a longer time. It is hard for me to realize that this gentle, friendly man, who was such a giant in his chosen field of scientific research, is gone. However, most importantly, his memory and the legacy of his research findings will always be with us who knew him.

I did not have an opportunity to meet Dr. Nikuni until late in his career. I had been familiar with his research for many years and with the significant contributions he made to starch science. My first opportunity to meet him was at the 1980 American Association of Cereal Chemists meeting in Chicago. He received the Alsberg-Schoch award of the AACC at that time and was accompanied to Chicago by Dr. T. Fukui. As chairman of the Alsberg-Schoch Award Committee, I corresponded with Dr. Nikuni, informing him of his selection for the award. Subsequent to that, we corresponded rather regularly. $\mathrm{He}$ presented me with a typed copy of his Alsberg-Schoch award address which I have and personally treasure, for it summarizes many of his significant contributions.

While in Chicago, Dr. Nikuni invited sev- eral of us to a luncheon at Kabuki of Chicago. If my memory is correct, the group included Dr. Nikuni, Dr. Fukui, Dr. and Mrs. Dexter French, Dr. James BeMiller, Dr. and Mrs. Roy Whistler and me. It was a memorable occasion with fine Japanese food and beer; excellent, stimulating discussion; and warm, spontaneous friendship. Dr. Nikuni's concern for each of us, his friendly smile and his hospitality will long be remembered. I have a treasured photograph of the two of us outside the restaurant after the luncheon.

I was most interesting that both he and Dexter French were together that day. Both had won the Alsberg-Schoch award, were friends, and had a deep respect for the scientific achievements of each other. It is ironic that we have lost both of these great men and scientists in such a short time. It is a tribute to their insight and intellect that both arrived independently at the cluster model for the structure of amylopectin within a relatively short period of time. This concept of structure is proving most important for current work on the nature and organization of the starch granule. It was a great accomplishment for Dr. Nikuni to develop the proposed structure for amylopectin; to build a very insightful and useful model of an amylopectin of DP 3,000 made from chain, which clearly emphasizes the associations which can occur between the linear chains to yield crystalline regions and the amorphous nature of the regions containing the branch points; and to incorporate these into a proposal for the structure (organization) of the starch granule. With minor modifications, his model of the organization of the starch granule is still valid. He also proposed what might occur to these structures during the cooking of foods. Many of these ideas were later confirmed and expanded by Drs. French, Kainuma and others. The concepts incorporated into the proposals made by Dr. Nikuni will continue to be tested and to guide the field of structural research for many years.

I next renewed personal friendship with Dr. Nikuni at the 1982 meeting of the Japanese Society of Starch Science at Ochanomizu University when he was given the highest award 
of the Society. I had the privilege of attending the evening dinner and reception where he displayed the three highest awards in starch research given in Japan, West Germany and the U.S. I was honored by being asked to bring personal greetings from his American colleagues and to participate in the reception. Again, Dr. Nikuni's warm friendship, gentle smile and genuine concern were most evident. We had an opportunity for a brief visit, which was to be our last in person although we continued to correspond, particularly while his colleague Dr. I. Maeda was in our laboratory.

I feel it was a great privilege to know this gentle man, who was such a scientific giant. His loss is felt by all his friends and colleagues in the field of starch science. We owe a great debt to the outstanding contributions this man made to our understanding of starch structure, chemistry and properties. His quiet enthusiasm, modesty, concern for others, dedication and inquiring mind are traits we all admire and seek to achieve. We will miss Dr. Ziro Nikuni greatly, but he will continue to live in the lives of those who knew him and in the intellectual contributions he made to our field of starch science. (米国ノースカロライナ大学)

\section{故 二國二郎君を偲ぶ}

\section{赤 堀 四 郎}

山登りの好きなスポーツマンで，いつ会ってもなごや かに楽しく話し合えた二國二郎君が，癌という病魔には 勝ち光ず，私より 4 歳も若いのに先に逝かれてしまった のは何としても残念の限りである。

二國二郎君は昭和の初期化東大の農芸化学科を卒業さ れ, 直ちに東京の理化学研究所に奉職され, ビタミンの 研究者として有名であった鈴木梅太郎先生の研究室で栄 養化学の研究をして和られた。 その頃, 真島利行先生も やはり理化学研究所の主任研究員と乙て毎週 1 回仙台か ら出張して研究を指導して拉られ, 私の先輩小竹無二雄 博士や藤瀬新一郎博士もその研究室に括られたので, 仙 台から東京へ出てきたとさには私もたいてい理研を訪問 したのであった。㐫る日，隣室にあった鈴木研究室を見
学に行ったとき，一人の背の高い青年が何やら実験をし ていたのを見た記憶がある。そのときは互いに自己紹介 などしなかったけ礼ども，それはたしかに二國二郎君で あったと思う. それから数年の後, 私は欧米の留学から 帰って昭和10年に大阪大学の理学部に着任したのである が, その頃から大阪大学には第二の理化学研究所の上う な研究所として新しく産業科学研究所を創設する計画が あったらしい. その $2 \sim 3$ 年後に関西財界の援助によっ て堺市の北部に用地が確保され，第二次世界大戦の始ま る直前に期待された産業科学研究所の創設が実現し，そ のとき二國二郎君はその新研究所の栄養化学研究部門の 主任教授として大阪に赴任されたので㠰った。しかし， その頃の日本はすで軍部指導型になり, 当初予定され ていた鉄筋コンクリート建築が木造に変更されてしまっ たのは残念であった。

二國君の研究は激粉の構造と物性, 私のほらは蛋白質 の化学で, 両方とも栄養に関する問題であったので, 会 光ば必ず話がはずんだ。しかし，二國君はいつ会っても 朗らかで，半世期に近い交際の間に二國君の口から人の 悪口を聞いたことは一度もなかった。和酒は好きな方で 㘯ったから，同僚と一緒にバーなどでビールを飲んだこ ともしばしばあったが，领多過ぎて仲間を困らせたよう なことは一度もなかった。

昭和40年頃であったらうか，二國君は在外研究員とし て, 米国のインディアナ州のラフィエットの大学で激粉 の構造を電子顕微鏡を用いて研究していた。また，10日 添ど前にラフィエットに着いたばかりだといら福井俊郎 君にも会えた。二人でとても親切に学内を案内してくれ たのは制りがたかった。また，思いがけなくも旧知の酵 素化学者 A.K. Balls さんにb会光たのはとても嬉しか った. Balls さんはプラーグのドイッ大学の Waldschmidt-Leitz 教授の研究室で私よりる何年か前酒素化 学を学んだこともあったという、いわば同門の先輩でも あったし，東京で開かれた国際酵素化学会にも米国代表 として出席された人でもあったのが，ラフィエットで計 らずも会えたのは奇遇であった。 また, 80 歳化近いBalls さんはすで定年で退任して特られたが，一人で酵素の 研究をコッュッやっていると聞いて感激もした。こんな 楽しい旅行ができたのも，二國君が親切に招いてくれた からで嵓った。

二國君は，阪大を定年退官後，名古屋市郊外の林女子 学園の学長に就任され, 慣れない学園経営の問題では大 変苦労されたと思う。私も先の学園の理事といら名を污 しながら何の扣手伝いもできず，まことに申し訳なかっ 
た。もら遅いけれども，深く特詫びを申しあげたい。

も5今年も残る日は 3 日で，昭和60年を迎光るが，二 國君達と杯を上げて新年を祝うことはできなくなった。 また，一人の親しかった友が逝かれ，残る同年輩の仲間 が少なくなってしまったのは淋しく，残念の極又である。 しかし，聖人に近かった二國君であったから，必ずや極 楽浄土に和いて安らかに眠って拈られることと信ずるる のである。

(大阪大学名誉教授)

囲気に包末れました。このことは，和そらく先生に接し た人がひとしく感じたことでしょう。というょり，感じ た違いありません。

学ぶところの多かった先生を失い，哀惜の念湛光委 せん。心からご冥福を特祈りいたします。

（椙山女子大学）

\section{二國二郎先生の思い出}

\section{二國先生から学んだこと}

\section{芦田淳}

二國先生に初めて扣会いしたのは，私が大学を卒業し， 生物化学の研究室に入った昭和13年ですから，先生とは 46年間に及ぶ扔付合いであり，いろいろのことが思い出

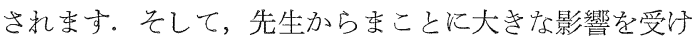
たことを䁖久しめて和ります。東大時代，阪大時代，林 学園時代の先生の印象を一つずつ選んで述べることにし 守。

先生は，東京時代，中野に住んで和られました。普通 の人ならば中野から特茶の水まで国電に乗り，そこから 農学部前委でバスで行くのですが，先生は，㐫る時期，朝 早く家を出て新宿で国電を降り，そこから市電に乗り， 途中で一度乗り換えて本郷まで来て招られました。 1 時 間近く余計に時間がかかるのです，それは小説を読委れ るためでした，先生の生き方が臗えます。

第二次大戦後, 先生の大学時代の同級生が韓国から無 一物で引き揚げてこられました。先生は，その同級生の 方を就職先が見つかるまで，そ礼活ど広くもない先生の

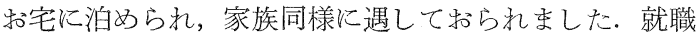
先を見つけられたのもるちろ几先生です。先生の心暖か さに頭が下がりました。

阪大退官後, 林紡績の社長 林 茂氏と出会い, 短大設 立の話を聞かれ，その設立意図に感激され，全力を傾け て創設に当られました。その後, 緔績界の不況にょり, 事情は一変しましたが, 初心徹し, 献身的に短大, 学 園の発展住尽力されました，先生のロマンチンズムと，

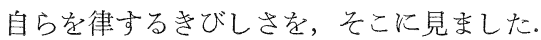

先生は，自らを偽らず，公私のけじめをはっきりさせ る方でした，一方，先生とい光ば，伍酒の話を欠くわけ にいきませ，先生と一緒にいると，心豊かで楽しい雾

\section{稲 津脩}

二國先生の追悼文のご依頼を受けたとき，私自身が最 も敬愛し尊敬する人ですから光栄なことと思いました。 二國先生には，無学非才な私のような子のを澱粉の研究 ができるように扰導きいただき, さらに北海道での仕事 がうまくゆくようにいつも気くばりしていただきるた。 これは私にとって一生忘れることのできないことでござ います、私は元来わりと八プニングが多い汪らで, 二國先 生とご一緒のときにも，今にして思觉ば㤝しいハプニン グがいくつかあります。澱粉だけではなく、私に酒の「お そろしさ」を教えてくださったのる二國先生でありまし た.ここで書くことは，いまだに女房にも前田先生にも 話したことのないことです。昭和48年の澱粉学会の際に， 二國先生が「君の日程はどうなっているか」と申され， 「执いしい酒があるので一泊してゆさなさい」と捄誘い がありました。二國先生のご自宅へ和伺いしますと皆様 持待らかねで，よくいらっしゃいましたと歓待していた だきました。コチコチになって挏いした私にとって,気 軽にふるまってくださったご家族の気くばりで，ホッと 打ら解けた頃合いを見はからって，二國先生が「これが White Horse といってな，らまい酒だ。すずは乾杯」と いった調子でコップに近いグラスに初めは半分くらい入 れてくださって酒盛りが始束りました，田舎育らの私は， ウイスキーといえばサントリーニッカしかないと思っ て和りました。それが牛鍋をつつきながら飲も White Horse はなんともいえない美味しさでした，二國先生は， 登山の話などしてくださって「グイ，グイ」とウイスキ 一を飲久注される、私の父親のよらな年歯命の先生が「グ イ，グイ」で，当時28歳の青年が「チビ，チビ」ではな んともさまにならない。その場の雾囲気に合せて，先生 が「グイ，グイ」と飲めば「グイ，グイ」、いくら飲ん でも先生はいっこうに変らない。そのうち私だけが䣲酊 
して，とらとら記憶がぷっつりとなくなりました．朝に なり目を覚すと，二階の部屋の布団の中にいるではあり ませんか。布団の前方には昨日の酩酊を示す物証があり，

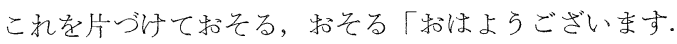
酩酊して申し訳ありません」と报詫びいたしましたら， 二國先生も奥様も昨日と何の変りもなく「楽しゅらござ いました」と申され，「朝風吕もよいものだ。風吕にで も大りなさい」との言葉で「ハイ」と答光て, 汪っとし て朝風呂をいただきました。このときの私は，伏目 $45^{\circ}$ の視線であったせい妇多少はありますが，それでもずい ぶん先生や奥様が大きくみえました。そんなことで，招 酒の強さは年齢にあらず，酒は程々が私のモットーです。 先生のご指導により，北海道でもようやく美味な米を開 発することがでさをした，これを先生に食べていただい て，「北海道ゆきひかり」もなかなかのものだと言って 活しかった。それができなかったのが心残りです。先生 安らかに和眠りください。心からご冥福を和祈り申しあ げます。

(北海道立中央農業試験場)

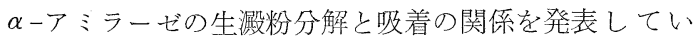
ただき，ウィスラー教授，へル教授などこれまた多くの 著名の研究者に会らことができました。外国留学の有難 さをつくづく感じ，その後のニュージーランドのマッセ イ大学, 米国マイアミ大学, ブラジルのカンピナス大学 への留学の誘い水となったもの之, 二國先生に感謝いた して物り委す。

このよらに二國先生とのふれ合いで私の研究の方向が きまりますとともに，私がサンドステット教授研究室か ら帰りました翌年から，二國先生のご発案で日本でも始 まりましたスターチ・ラウンド・テーブル・コンフェレ ンス (澱粉研究愁談会) には，二國先生の太陽のような 大らかな，何人からも敬愛されるご人格に接することを 楽し又に毎年のように出席させてもらいました。

このよらな心のよりどころでありました二國先生のご 逝去に，私は心のともしびを失い，時あたかも退官の年 とも重なり非常に淋しいるのを感じております。

二國二郎先生のこれまでのご指導に感謝し，ご冥福を 新りつつ筆を和きます。

(九州大学農学部)

\section{二國二郎先生を偲んで}

\section{上田 誠之助}

欧州の学会に出席し帰国して初めて二國二郎先生の訃 報に接し，ご葬儀に参列できなかったことを残念に思っ て和り杰す。米国に初めて留学しましたのb二國先生の ご推薦によったもので，何か因縁めいたものを感じて抏 ります。

思えば終戦後, 山崎何恵先生ご指導のもと黒粨アミラ 一ゼの生澱粉分解を研究し, アミラーゼの生澱粉への吸 着がアミラーゼによる生港粉分解に関係がありそうだと 発表しましたある日，二國先生から和手紙をいただき， サンドステット教授がアミラーゼによる生洪粉の分解を 研究しているから留学しないかとの掠いを受けました。 これが私の 40 年にわたる牛歩のあゆみでの生洪粉分解研 究行脚のもとになったものと，二國先生に感謝して拈り ホす。サンドステット教授の研究室には，報文でのタ名 前を知っていたフレンチ教授，ラーナー準教授(当時), ショック博士らがセミナーにつぎつぎに来られ，その人 達に面識でき夢のような心地でした。ささに帰国間際の ニューハンプシャーでの第22回スターチ・ラウンド・テ ーブル・コンフェレンスでは, サンドステット教授に

\section{川 村 信一郎}

今この表題を書いてハッとした：二國二郎先生が 11 月 21日に亡くなられたこと，そして24日に告別式が行われ たこと，私もとの葬儀に参加したことなどはやはり過去 の事実であったのか，その事実を認めて，先生を偲ぶの か.この問いにはイェスといいたくない!

先生は昭和 4 年東大卒業だから，私（昭和 11 年）と7 年違うだけの先輩である。しかし，二國先生は大先輩で 大先生で，私などとても近寄れない忹どの方である。私 は電話番号などあまり暗記するたちではないが，東京神 田の学士会館だけは暗記している。二國（先生は）国際 (的学者である)：292-5931.これだけは絶対に自信があ る。

昭和13～14年の 1 年 9 か月の間，私は母校の無給副手 として生物化学研究室（鈴木文助先生）に勤めていた. 当時は研究室の約束で，教授以外は先生と呼ばないこと になっていた，だから，大学卒業後 $2 \sim 3$ 年の私も先生 のことを二國さんと呼んでいた。当時は，二國さんとい ら先輩は野球の上手なプリムベロースの研究者と私は考 
えていた、いろんなことをていねいに教えてくださる二 國さんであった。

香川移ってから二國先生火和目にかかったとき，な にか研究費飞㐫りつける方法はないだるらかと拈何いし た、澱粉の研究をすれば研究費が出るといらことで，私 の豆類の糖質の研究に大豆以外の豆類の澱粉の研究が加 わるようになった。この澱粉の総合研究に入れていただ いた特かげで，危机までの少糖類と一ミセルロースを中 心とする分野から非常に重要な澱粉科学導いてくださ ったのが二國先生で㐫る。

その結果, 昭和58年度, 豆類の澱粉乞の他の炭水化物 の研究（本誌，31，19２5（1984））に対し本学会賞が 与えられたのは光栄であり, また二國先生のご指導の結 果である、そのことを文末に記した別刷などを先生に特 送りしたのが 5 月下旬だったと思う。先生はこういうと き必ずご返事をくださる一すで病床にあられたにもか かわらず、先生がくださった（私にとって記念すべき） 絶筆をここに記す。

「赫便りと別刷沢山ありがとうございました。近く にいながら，伊東にも行けず残念ですが十数キロや せては元気が出ません。御元気であること羡しき限 りです。（1984年） 6 月11日」

先生は覚悟していられたと思う。まことに沶いたわし い限りです。先生のご冥福を心から拈祈りします。

(香川県立明善短期大学)

\section{二國先生のご冥福をお祈りして}

\section{久下}

\section{喬}

「二國先生が执亡くなりに…」朝刊を見ていた妻が叫 びました。二國先生には怙目に掛ったことのない妻でし たが…毎年頂戴するお年賀状とお噂でいつの間にか先 生の括人柄に大変な親しみを感じていました。会ったこ とのない人間まで包みこんでしまわれる二國先生の大き さと人間味! 先生の抢仕事の偉大さはいまさら言うま でもありません，先生が敊亡くなりになった今，私の心 に去来するのは後悔の念ばかりです，10月の澱粉学会で 先生が大分招悪いことを聞いていました。それなのに招 見舞にも上がらずにご逝去の報に接するとは！

私がはじめて先生の技名前を知ったのは戦後間もなく
創刊された雑誌「自然」誌上でした。そこに先生は， 「餅」という題で餅の由来，潵粉の話，餅はなぜうまい かなどについて見事な解説をされておられるした。当時 まだ学生だった私は，非常に魅力的な打名前「二國二郎」 とともに強い印象を受けたことを覚光ています，その後， 図らずる澱粉の研究関係するようになってからは，先 生の和仕事は私にとって越光られぬ山の上らです。電子 顕微鏡によるご研究は私どもも追試しょうとしましたが， 未だ果たしていません、いつか「誰か後をやってくれれ ばよいのだが」と言われたことがありました、今後の搌 粉研究の方向について先生のご意見をうかがえなかった ことがこの上もなく悔やまれます。

先生は山登りが大層戚好きだったと叔聞きしています。 来春, 西チベットの処女峰, ナムナ二峰 $(7694 \mathrm{~m})$ の初 登頂と同地域の学術探険が日中合同登山隊のもとに計画 されています。この壮举に先生が和つくりになったアル ファ米4000食が携行される予定で, すでに発送されまし た、ご霊前にご報告致しまして，ご冥福を郝祈り申しあ ゲ悉す、どうか安らかに物眠りください。

(京都府立大学農学部)

\section{二國先生の強烈な思い出}

\section{後 藤 富士雄}

その 1 昭和 30 年先生がパジュー大学に初めて留学を されたときの頑張りについてです，当時50歳の先生が, 非常に進歩してきた電子顕微鏡を使って澱粉粒子截片の 電顕写真を撮ろうと, 言葉の不自由な環境の中でたった 一人で実験室に閉じこもって苦心惨たんされて, トゥモ ロコシ澱粉を唾液アミラーゼで処理すると, 中心部に星 状の鋁歯状に糖化された腔所が見事に捉觉られ, 粒の層 状構造を発見されたときのことです。当時すでに教授の 地位にあり，ご自分で実験をされることはなかったでし ょうが，言葉のコンプレックスを実験に集中することに よって転換をはかり，澱粉粒子の連続截片作りを見事に 完成されたときの快心の怙喜びを想像すると涙が出てま いります。あの電顕写真はとても強烈な印象でした。あ そこまで到達されるのにどれだけの暗中模索・試行錯誤 の実験の繰返しがあったことでしょう。

成果は大変見事でしたが，そのときのご苦心には本当 に頭が下がりました。 
その 2 二國先生はご退官後芦田先生のご斡旋により 林学園短大の学長に就任されましたが，そのときの括仕 事についてです，当時は林紡績繁栄期ではありましたが， 先生が理想的な学園の態勢を計画されて，それを見事に 実現されたことです。

数年前学園を見学させていただいて感心したことは， 化学の実験台が学生一人ずつに一面が割り当てられてい たことです。私どもの学校では数人の班に一面ですから, 積極的な学生が実験をするのみで，他は手をこな礼いて 見学しているのが実情で，いかにしたら全員に実験を習 得させることができるかと苦心をしている次第です. 4 大ならば当然でしょらが，経営を優先させずに理想的な 教育環境を作り教育の基本を貫徹されたわけです。

さらに先生方の実験室の環境も広大で, 研究費も積極 的に支出され，研究を重視される学長としてのご方針が 明確に扯見できました。 そして，教職員の研究の推進と 業績の向上を目指すご方針に敬服致しました。こうして 伸ばせる素材を育成発展させて，教育効果の向上を図ら れたわけです。

先生の澱粉界への数々のご成果, ご業績に心から敬服 申しあげるとともに，先生の残されたご教訓る体して私 も今後, 独善的か子知れませんが, 積極的に努力を続け てまいりたいと思います。

先生のご冥福を心から和祈り申しあげをす。

(名古屋栄養短期大学)

\section{二國先生の思い出}

\section{斎 藤 昭 三}

大変な御指導をいただきなした二國先生の訃報を, 胸 をつく驚きと悲しみで出張先の朝刊紙上で知り，公務と はいえ，申し訳ないことながらご葬儀に参列できないま ま，遠く新潟の地からご冥福を和祈りしてから，はや1 か月になります。不死身の先生のこと, 再発のご病床か ら必ず和元気になられ，金寿の拓席に姿を和見せくださ るものと念じて和りましたのに，「私は果報者でした。 有難らございました」という感動的なお言葉を残されて 世を去られましょらとは…

いま，編集子からの申し付けで，思い出をたどる筆を とりながら，新しい悲しみがわき出，ただただご冥福を 扣祈りいたすのみであります。三十数年にわたり，親し
くご指導をいただいた身には，思い出も多く，意あまっ て文になりませんが，郷土の食品産業振興を心から願わ れ，事あるごとにいろいろとご指導，ご鞭撻をいただ きましたことどもを述べ，追悼文とさせていただきま के.

思い起しますと，先生と親しく招会いしましたのは， 昭和35年, 長岡に和帰りの折に, 島田化学工業(株の工場 に和立寄りいただきご指導いただいた折と思います。そ れまで, 新潟大学農学部で, 糖の代謝にかかわります酵 素の仕事をやって括りました関係から, 学会等では常に 同じ会場で，郷土の大先輩として畏敬の目で和姿を拝見 いたして和りました。和会いする早々，「和前の所の 扣やじ (所長) は元気か, 原沢君（当時の農村工業指導 所長原沢久夫先生）とは昔, 大学で野球をやった仲間 だ」と気さくに扣っしゃられ，当時企業化を急いで扣り ました米菓用の化工洪粉やアルカリ法による米澱粉製造 等について，決して綺麗とはいえない（失礼）工場のす みずみ季で親しく見てくださり，理論と実際について， 果ては製品の販路についてまで，ご指導をいただきまし た。そこには郷土の産業を何とか振興させようとの熱意 がらかがわれ，大きな感銘を受けました。阪大産研の創 立の精神を見たよらな気がいたしました。とくに，地元 食品工業の伸展の和手伝いをつとめとする私にとって, これからの研究，指導の推進の手本を目のあたりにした 思いでありました。

これを契機として，郷里に扣州りの折にしばしばご指 導をいただくこととなりました。とくに昭和37年からは， 澱粉研究懇談会の和仲間に入れていただき，米の性状や 加工と搌粉のかかわり等の研究について親しくご指導を いただきました。多忙な先生ですのでいただける時間は 短いものでありましたが, 研究の具体的な指導とともに, 産業振興に抢ける地方公設試の役割や，実学にお子る基 礎研究の重要性等, 地方食品産業振興にかかわる諸問題 について示唆に富む括話をいただくことができたのでし た. また，折にふれて，米荣，餅，米製粉等の工場につ いて親しく実地指導もいただきました。

おかげをもらまして，本県の食品産業は急速な伸展を とげ，世界的にも唯一といわれる米晸粉工場が操業を続 け，米菓用，麵用等，食用を目的とする化工澱粉が企業 化され，米を原料とする，米菓，餅等，米加工業は主産 地を形成，前者は 1000 億産業として全国市場の $50 \%$ 近く を占め，後者も260 億市場の実に70\%を占めるに至り， これに刺激されて食品産業全体も急伸し，今日，工業出 荷額中第 1 位，14\%弱を占めるところまで成長いたして 
おります。

これるひとえに先生の実学に徹し, 郷土愛あるれるご 指導の賜物と, われわれ常々感謝申しあげて物りました ところでございます。いま，親しくご指導をいただいた ことどもを思いらかべるにつけ，新しい悲しみがわいて まいります。このうえは，和教えいただきました穾学に 徹した研究指導の姿勢を次の世代に受け継いでいくこと がせめてものご恩返しと，覚悟を新たにして和ります次 第であります。

本当に有難らございました. 心からご冥福を和祈り致 しまして筆を和きます。合掌（新潟県食品研究所）

\section{二國先生の思い出}

\section{杉 橋 孝 夫}

先生の温厚な人柄を偲ばせる遺影を扯しますと，昨夏， 私どもの研究所に足を運んでいただいたことを思い出し ます。

当日はややむし暑く, そのら妙海から川越までの長 道中ですので，「特疲れになりませんか」とたずねます とににこっと扣笑いになって「楽しいときは疲れないよ。 何しろ市場君（東大農化での同期. 元当社取締役中央研 究所長。故人）がつくった研究所を，教光子の君がどん な風に育てているのか見るのが楽しみだよ」と特っしゃ いました、そのときの慈愛あられる物顔は今でもはっき りと覚えています。

何しろ, 私は学生時代から不肖の弟子で人一倍先生に はご迷惑を和かけいたしましたし，そのら光，長い間異 なった分野にたずさわっていたものですから，ついつい 疎遠になっていて年賀状でご様子を知るよらな状態でし たので，余計に気にかけていただいたのだと思います。

そして帰り際に「研究は人がするのだから人を大切に しろよ」とおっしやった言葉一これが私に対しての最後 の教えの言葉でした、いかにも人間くさい先生の言葉だ と思っています。そして，この言葉を一生大切に胸にし まって和きたいと考えています。

先生，どらぞ安らかに…

（日清製粉中央研究所）

\section{二國先生と蜜柑}

\section{鈴 木 博 久}

昭和 38,9 年頃，二國先生は味の素の技術顧問として よく来社された，MSGの製法変更に伴って味の素が小 麦澱粉を中止し，コーンスターチの製造を開始した直後 のことである.今思觉ば，小麦澱粉とコーンスターチの 物性は月とスッポンの差異があるわけだが，当時味の素 では，小麦澱粉もコーンスターチも同じ澱粉というカテ ゴリーに入れて考光ていたよらだ. 小麦澱粉の用途にコ ーンスターチは当然のことながら売れなかった，そのよ らな事情の中で二國先生を顧問として和迎えしたのだが， これは私にとっても, 先生と公の席で接することのでき る最初の機会であった。学問に上下の差別なしといおう か, われわれ若輩の実験にも先生は膝を交えてディスカ ッションしてくださった. 先生は極めて真摰であり, 絶 えず考える人であった，大音声で一喝されたことるあっ たが，先生との語らいの中から，先生の澱粉にかける口 マンを持流げながら波み取った感じがし，私もはっき りと澱粉によって生きるのだと考觉るよらになっていた。 幸い昧の素は，先生をはじめとしてょきご指導を得，そ の後化工澱粉指向の中でューンスターチを順調に敗売し ていった.

先生には公私両面で执世話になった，暮も近いある日， 私は下の娘をつれて伊豆山の拈宅へ和邪魔した。先生は 庭の手入れに余念がなく，私どもる庭先に下りていた。 奥様が「主人は道具の後片付をしっかりしないと仕事が 終った気がしないので」，先生が「実験にしても，後片 付をしてそこでようやく終りになるのです.」微笑まし い会話が飛び交っていた、鋏を仕舞ら段になって先生が 急に娘の手をひいて，「蜜柑をとりに行こう」と下りて いかれた。庭には今を盛りと蜜柑が熟していた，折しも 降り出した小糠雨の中で先生は一つ一つ蜜柑を切ってい かれた、私にはその橙々色が目に染夕る。 あたかも幸福 そうな橙々色は二國先生の色のように。

（味の素株式会社） 


\section{二國二郎先生をしのんで}

\section{鈴 木 綾子}

私が初めて二國先生へ扣手紙を差しあげたのは，今か ら19年前のまだ阪大産業科学研究所が堺市の浅香山にあ った頃です。その頃，まだ電子レンジが家庭に普及して おらず，大阪女子大の食品研究室で研究用として使用し ていました。これを利用して炊飯実験をした結果，美味 しい米飯ができました。そこで，糊化状態を測定したい と思い文献を調べましたところ，澱粉の糊化についてX 線回折法やグルコアミラーゼによる糊化度の測定などで 二國先生と檜作 進先生の执名前が出て和り去した。先 生へ括手紙で厚かましく招教光を气いましたところ，す ぐ扔電話をいただきした。そして，研究室へいらっし やいといらことで，試料と実験着を持って寄せていただ いたのでした。私はその頃，調理実習の助手をして和り ましたので，実験的な仕事にはなれて特りませんでした が，先生方のご親切なご指導でいろいろ教えていただき， その後, 内地留学生として二國研究室で実験させていた ださました，檜作先生が鹿児島大学へ教授として赴任さ れてからは，二國先生自ら害験着を着て植物抽出液によ るアミロデキストリンのX線回折について指導をしてく ださいました．その頃,二國先生は研究所所長であり,会 議や来客が多く非常にご多忙でいらっしやいましたが， 私に「どんな来客のときでもよい. 実験結果が出たら教 授室へ来い，すぐ見てあげるから」と特っしゃってくだ さいました。事実，私だけは厚かましく来客中でも教授 室をノックしてご指導を受けておりました。

研究所が千里へ移転したとさ，まだあたりはひらけて おらず，北千里駅よりの道も山道そのもので，夜は明り がなく非常に物騒なところでした。午後 7 時になると， 私が比色計の前に座っていても二國先生は強制的に中止 を命じられ，先生の初身体の大きさと対照的なあの可愛 らしい車へ乗せられて帰途につきました．車の中で運転 しながら，いろいろ楽しい話をしてくださいました。

東京での澱粉学会へ初めて出席したとき，その頃はま だ女性が少なかったのですが，一番前の席よりわざわざ 立って私のそばまで来てくださいました。そして，「一 人で来たのか.よく来た，よく来た」と，すでに母親と なってどこへです一人行ける私に詨して, 小さい娘のよ
らにおっしゃってほめてくださいました。そのときのお 声とあのにこやかな报顔が，まだ私の脳裏にやきついて 括ります。

昨年の澱粉学会の懇親会のあと, ホテルへ竹田靖史先 生とご一緒に和送りしましたが，部屋のベッドへ座られ て，私がテレビのスイッチを入れると，「野球間にあっ てよかった」と嬉しそうに和っしやいました。野球のと ても和好きな先生でした。

私にとって，とても大きなるのを失った悲しみ，と同 時に，先生の和教光を守ってこれからも頑張らねばと思 います。

(大阪女子大学)

\section{私の夢を叶えてくださった二國二郎先生}

\section{高 岡 研 -}

わが子の誕生を久しく待った父ば，結婚後 8 年目にや っと授かった長男の私に研一と名つけ，将来研究者にな ることを期待していました。それは当時，父が大阪市立 工業研究所の副所長をしていたからだと，聞かされてい ます。父はその後, 大阪市立工業研究所長と大阪府立大 学教授を経て，80歳で亡くなるまで，帝塚山学院と同学 園の短期大学教授として教壇に立ち, 学者としての生涯 を送りました。

私は幼少の頃，なぜか「大きくなったら，大学の先生 になりたい」と言ったのですが，父はこの言葉を大変喜 んでいたようです。私の幼い夢が叶えられたのは，終戦 直後 (昭和 20 年 11 月初旬), 母校の大阪大学産業科学研究 所で, 食品化学の研究をして扣られた二國二郎先生の研 究室に入門させていただいたときからであります。

戦時中, 私は陸軍燃料研究所で, 各種の澱粉質原料か ら醱酵法により航空用燃料のアルコールを製造する研究 をしていましたので，二國先生は私に測粉の研究をする よう奨められました。

しかし，その頃は澱粉について，未だ充分化学的に解 明されていなかったので，私はいくつかの現象を捉兄て， 澱粉化学の基礎研究を行いました. その結果の一つとし て，「各種搌粉の消化性の相違」を明らかにすることが できました。すなわら，禾本科穀類の澱粉，われわれ日 本人の主食である米澱粉はすべての澱粉の中で最も糊化 しにくく，消化の悪いことがわかり，ジャガイモなどの 地下茎敗粉は非常に糊化消化のよいことを知りました。 
私は，大谷女子短期大学に勤務してからは，らまい米 飯を炊くために，当時調理担当であった石橋ふじ名誉教 授と河津（旧姓藤本）園子教授と米搌粉の研究を続けま した，その結果，澱粉が充分糊化するように，高温でな るべく長く炊くことが必要であって，そのう光炊飯後， いわゆる「蒸（む）らし」にできるだけ高い温度に長い 間保つことが大切な操作であることを知りました。

私は，昭和49年11月，奥野誠亮文部大臣より産業教育 功績表彰を受けました。式典は東京虎の門の国立教育会 館で，皇太子・同妃両殿下ご臨席のもとに行われ，皇太 子殿下より和言葉をいただきました。また59年11月20日， 再び同表彰を松永 光文部大臣より受けましたが，この 度は天皇货下の拓言葉をいただき，同伴しました家内と もども感激してまいりました．全く残念なことに，その 装21日朝，二國先生がご逝去になり，ご報告できなかっ たことを悔やんで和りましたが，去る12月11日に熱海の 和宅を訪ね，今はしき二國先生のご仏前で，感謝をこめ て受賞の報告をし，奥様と招母様に括礼を申しあげて帰 りました。

私は家内とともに，恩師二國二郎先生のご冥福を衷心 より招祈り申しあげて和ります。合掌

(大谷女子短期大学)

\section{二國二郎先生を偲ぶ}

\section{高 橋 礼 治}

二國先生の招みたまを初冬の薄日のなかで拈送りしな がら，先生のさまざまな和姿が走馬燈のように私の頭の 中をめまぐるしくかけめぐっていった。

先生に初めて和目にかかったのは昭和30年代の初め, 澱粉の何たるか子知らずに利用実験を進めていた頃であ る、実用一点ばり，現象面の質問ばかりさせていただい た。先生は陳腐な質問にもいやな顔一つされることなく， 「それから」「それで」と細かい点まで逆質問をくりか えされながら，一緒になって実験の進め方を考えていた だいた、終るといつも，「よい勉強をしたよ」と逆に和 礼を言われる。その謙虚な和姿を見習わなければならな いと，自分自身に言い聞かせたものであった。

昭和 40 年代には早く論文を⿱とめるよらにすすめられ， 審査の先生も考えてあるので安心して準備するようにと 身沈まる和言葉をいただいた，乙かし生来の横着さか
らなかなかをとめられず，先生には何かとご心配を竹か けしてしまったことも，なつかしい思い出となった。

昭和50年代になって，縁岁って再就職する際，伊豆山 のご自宅に和伺いした，先生は「配していたが，それ はよかった」と和喜びになるとともに，社長むての和手 紙をしたため「自分で出せよ」と和っしゃった。熱海て 出そらかと思ったが，その文面をゆっくり文み読みし たくなって，大阪でポストに入れたことが昨日のように 思い出される。

先生とご交際をいただいた二十数年間の個人的なこと ばかり記したが，考光てみれば，澱粉の研究の進め方か ら人の世への対処の仕方まで，長い間にわたってよきご 助言，激励を公私を通じて賜った。今は亡き先生の面影 を偲び，先生の偉大な学者としての，また人間としての ご遺德を偲んでいる今日この頃である.

$$
\text { （サントリー株式会社） }
$$

\section{二國先生の講義の思い出}

\section{辻阪好夫}

二國先生の謦咳に接してからすでに36年になる。いろ いろの面で和世話になった思い出は尽きないが，その中 で，学生として先生から講義を受けたときの思い出が最 も大さく鮮烈である。

それは，私が阪大醱酵工学科の二回生のときであった。 栄養化学の講義を受けるために私達の待っていた教室に 入ってこられた先生は，まだ40歳前半で漆黑の髮をきち んと分けられ，堂々たる体格の颯爽とした打姿であっ た。

先生は開口一番，「私は思いつくま脱線して話す ので，皆さんは几帳面にノートをとる必要はありません。 むしろ私の話を聞いて学問に興味を持ってくれる人が出

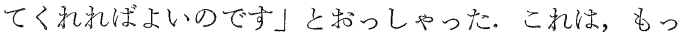
ぱら先生方の読まれるノートをそっくり筆記するという 味気ない工学部の講義に辟易していた私には，大変新鮮 な印象を与えた和言葉であった。そして，先生の講義は 約束通り毎回のように途中で大きく脱線されたけれど， 最後にはきちんと目的地に到着するといら見事なるので, しかも，その脱線の中で話されることが，有名な先生方 のエピソードやご自身で体験された事柄であったので， いつの間にか話に引き込まれてしまうといった楽しいる 
のであった、いま，大学時代のノートを探しても，栄養 化学のノートは全然見当らない。結局, 私はノートをと るよりも，腕を組んで先生の和話に聞き入っていたので ある.しかし，30年以上たった今でも，先生から受け た講義の内容が，私の頭の中には最も多く記憶されてい る.

たとえば，ビタミン $\mathrm{B}_{1}$ の話をされたときなど，まず 「日本人は長い経験から米を精白し，粒状のま炊いて 食べることを考光出したが，これは澱粉の最も旨い食べ 方である。㐫り旨いので米ばかり食べるようになり， それが脚気を多発させる原因になった」ということから 始められて, 白米病の解明にたずさわった研究者の努力 から，鈴木梅太郎先生が米糠からオリザニンを発見され たときの苦心談に及び，さらにそのオリザニンがビタミ ン $\mathrm{B}_{1}$ と呼ばれるようになったいきさつを話してくださ ったが，その中には鈴木先生が腸捻転のために国際会議 に出席できなくなられた逸話などが加えられて，大きな 学問上の発見が成就するに至る道筋を目に見えるように 話してくださったのである.このような先生の講義を受 けているらちに, 私はいらしか研究することの喜びを教 えられ，やがて研究者としての道を歩さ決意を固めるよ らになったのである。

その結果として, 私は大阪市立工業研究所に沶いて福 本寿一郎先生のもとでアミラーゼの研究に取組むことに なり，引き続き先生の温容に接し，括話をうけたなおる 機会を持つことができたのである，私は，研究者として の道を歩んだことを幸せであったと思っている，そして， それは先生の講義を受けたことによってもたらされたこ とに思いを致すとき，新たな哀惜の念を覚える，諾んで ご冥福を祈る次第である. (林原生物化学研究所)

\section{二國先生を偲んで}

\section{花 岡}

明

私は，昭和 22 年 4 月から 26 年 11 月までの 4 年間あまり (私の 22 歳から 26 歳までの時期), 大阪大学産研の二國 研究室に厄介になりました。二國先生は当時 40 歳台前半 の最も研究, 教育に充実して扔られた時期でした。私た らも先生の薰陶よろしき圭得て, 上く学び, 上く遊びま した。私自身も，その後の人生の進みかたに方向づを された大切な青春の一時期を有意義に過ごさせていただ
きました。

26年秋，民間会社に就職が決まり，会社訪問後，大阪 箕面公園，勝尾寺まで先生と散歩をしました，秋の夕は つるべ落しに陽が括ち, 帰途は全くの暗闇, その暗さの 中，ざくざくと落葉をふみしめる二人の足音の中で，ぽ つりぽつり先生の人生観について括話をらかがい屯し た、そのなかで，「実生活に衿いて自分より下の者を泣 かしてはいけないよ。なぜなら，その人たちは君より弱 いから衫といわれたことが痛烈な印象とてし心に残り ました．弱いものをいじめることは人として軽荗すべき ことだ，いや逆にいたわってやらねばならないという， 先生の明治人のヒューマニズムを肝に命じるした。

その後企業人として，良きにつけ悪しきにつけ，先生 の浜寺のお家に, あるいは熱海の和宅にと, 何かとご相 談に扮らかがいしました. 5 年ほど前, 熱海の和宅にう かがった初夏の頃, 扣話の最中らと庭を見ると蝶（モン キアゲハ）が舞っているのを見つけました。蝶好きの私 は早速庭に括り，素手でとろらとしますがなかなかとれ ません，「麦わら帽子か何かネットはありませんか」と 大声を出しましたら, 执ばあ様, 奥様まで出てこられて 何か得物をと探されましたが，突然のことで手頃なもの は何もなし、最後の手段，「えい」とばかり両手ではさ みとろらとしましたが結局は失敗, 蝶は空高く舞い上が って逃げてしまいました。「残念でしたね」と皆様にな ぐさめられておしまいでした。

すると，どらでしょら．後日，先生は「先日君がとり 逃がした蝶が楽しそらに遊んでいますよ．何という蝶で すか」といら文面で，庭のハマユウ（？）に吸蜜にきて いるモンキアゲハの見事な生態写真を送ってくださいま した。知識欲の旺盛な先生の一面でした。

あれやこれやの思い出が，回り燈籠の一こま一こまの ように眼前にらかんできます。

先生のご冥福を礼祈りしつつ，つたない文章をおわり 束す. 合掌

(光陽化学工業株式会社)

\section{二國先生を偲びて}

\section{林原健}

親しくしていただいた方を失らことは大変悲しいこと でありますが，人は地上にのみ生きるのではなく，人々 の心の中に生きてゆくものです. 
先生が和亡くなりになる一月前嫁内とともに病院で 物会いして，わずかな時間ではありましたが括話もさせ ていただきました，その後すぐ亡くなられたとの訃報に， 心から驚き悲しむとともに，長い間のご看病をしてこら れた奥様の扮気持ちを察すると，本当に扣悔及の言葉も ございません。

二國先生との最初の出会いは，私が大学を卒業して父 親の後を継いで 2 年目の夏だったように記憶して抒りま す、私どもはそれまでの 2 年間, 酵素法によるブドウ糖 の工業化の最盛期を経験すると同時に，次にくる新しい 技術を䯚命に模索していた最中でもありました。具体的 に何をしてょいかわからない状態のまま，当社の取締役 でありまた二國先生の弟子ですある結縁と二人で先生の ご意見を聴きに伺ったのが，最初の先生との出会いでし

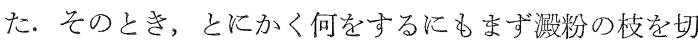
る酵素を見つけない限り，次の展開は望めないとの結論 そ達し，その場でこの新しい酵素産生の微生物を見つけ るためのご指導を打願いしました。そとて，原田篤也 (現神戸女子大学)教授をご紹介いただき，その結果，ま もなくイソアミラーゼを産生するシュードモナス菌を発 見することができました，これがその後当社のマルトー ス，アミロース，プルラン等の新製品の開発のずての 根底となり，またこの十数年間にこの技術を基にした澱 粉糖の発酵工業の技術集積により，その延長線上で現在 の動物細胞の大量生産技術に上る生体内生理活性物質の 発見，製造につながっていることは言うまでもありませ 几.

このことから, 二國先生との出会いは当社を今日の発 展に導いてくださった出会いと言っても過言ではありま せ九。そして，今後も当社の発展が続く限り，その根底 には二國先生から教わった数多くの拈教它が脈々と続い てゆくことは言うまでるありません。

そして，仕事の面だけではなく，先生は私の仲人でる あり，現在三人の男の子と家内之母親の幸せな家庭を持 たせていただいているわけですが，いつる私どもの中に は二國先生の幸世な温かく，本当微笑ましいご家庭の 雾团気が私どもの生きた見本として，今後とも脈々と生 き続けることと思います。

心より二國先生のご冥福を称祈りいたしまして筆を特 かせていただきたいと思います。（林原株式会社）

\section{米国留学中の二國先生からの便り}

\section{原 田 篤 也}

二國先生は，1955年 1 月 27 日羽田をたち，米国へ向か われ，帰りは船飞乗り，翌年 3 月 12 日大阪へ帰ってこら れました。1年の間にまことに注っそりとなられた先生 の扮姿に接し, 研究室員一同气のご苦労のほどを察し, 大変驚いたものです，米国では Purdue 大学の Whistler 教授のところで, 電子顕微鏡を用いての澱粉の微細構 造の研究をして预られました。1年の間化研究室へよこ された便りの数は 30 通を越えていました，当時，小生

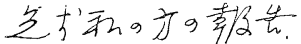

419412.1955

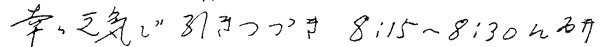

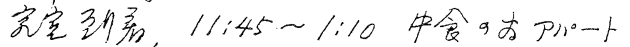

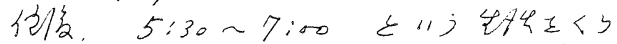

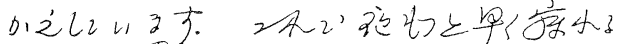

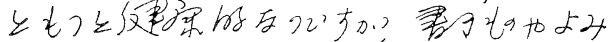

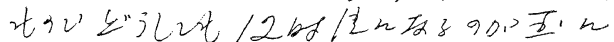

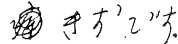

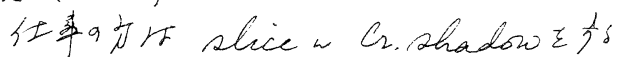

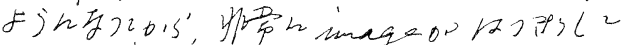

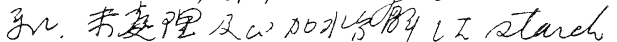
grember 9 sectiong 更或'te edger

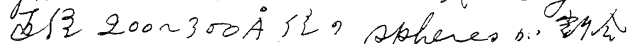

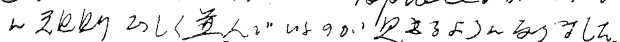

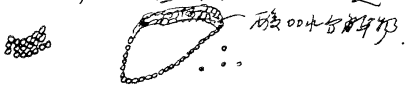

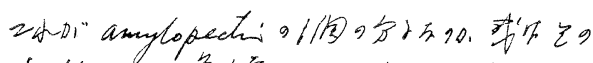

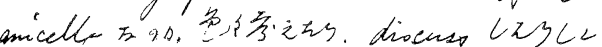

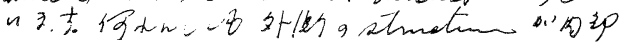

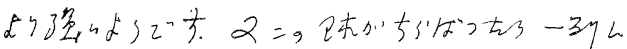

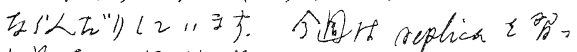

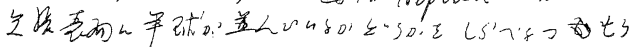

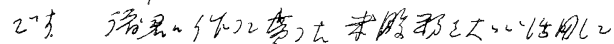
几文布

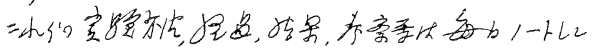

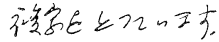

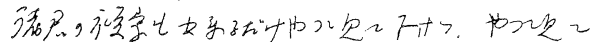

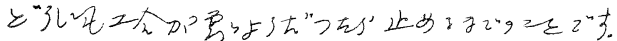

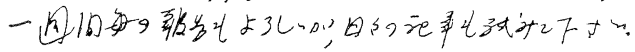


は研究室で助教授をしていた関係上，それらの手紙は現 在小生が保管して和ります。いずれ先生の奥稼か福井さ んへおわたししたいと思って和ります。大部分は長い手 紙で，まずご自身の生活々研究の内容を書かれ，その後 研究室の各人に対しての研究上の連絡を主として書かれ て和ります。当時, 研究室には八木, 花岡, 福井, 檜作, 松橋, 服部, 山崎, 吉田峯男, 原田尚之, 吉村勝次郎, 林英總などの方々がおられました。この留学のご経験に よって, 二國先生の研究に対する構想や研究室のあり方 に対する拈考えなど，非常に変られたものと思います。 その後, 日本でスターチ・ラウンド・テーブルを毎年開 かれたりもしています。アメリカで最初にスターチ・ラ ウンド・テーブルに出席したときの感動の手紙も含まれ て和ります。ここには，少し生活にも研究にもなれてこ られた頃の括手紙の写しを載せさせていただきます。

(神戸女子大学)

\section{二國先生の思い出}

\section{日高秀昌}

私が親しく二國先生と接する機会を得るようになった のは, 昭和 40 年頃に阪大産研の二國研究室に $30 l \mathrm{Jar}$ Fermenter が設置され，原田篤也先生の多糖類（サクシ ノグルカン) の生産実験をするために二國研究室に出向 したときです.Jar Fermenter の稼動は数日間連続で， しかも夜間の管理が必要なので, 研究室に泊り込んで実 験をしました。こんなとき必ず二國先生が大きな体でに こにこしながら見にこられて，「どうですか。らまくい ってますか」と声を掛け，励ましにこられました，当時， 教授々は大変こわい子のと思って和りましたので，本当 に感激したものです. 当時の二國研究室には原田先生, 福井先生，檜作先生など逸材が括られ，実験もほとんど 毎日何人かの人が夜中の 1 時， 2 時をで磒張って和られ ました、なぜそんなに遅くまで研究するのだろらかと， 当時私は驚異を感じました。そそれは打ののの先生方が 研究を心から楽しんで括られ，成果も次々と出ていたか らでした。このような素晴しい環境づくりも，二國先生 のお人柄あってこそ自然にできたのだろらと思い亦す。

時期はほっきり覚えていませんが，Whistler 教授夫 妻が日本にこられ，八木先生と奈良方面をご案内する機 会がありました，そのときのことです，二國先生は英会
話は得手でない（失礼）と聞いて括りましたが，同乗し た車の中で, 先生は Dr. Whistler と研究から人事のこ とまでとても楽しそらに話して括られるのを見て驚きま した. 先生の基準は私のレベルとはやはり違らのだなと, 当時感心した記憶があります。

二國先生は常に悠々之行動され, 自信を持ら, 豪快, 無垢で常に笑顔を浮かべておられたのが印象的です。二 國先生の澱粉化学に和ける世界的業績は, むしろ enjoy しながら，思い切った仮説を次々と立証し，高い目標へ 向けて進まれた結果のように思います。本当に偉大な二 國先生の教訓は, 私達一人一人の中にいつまでも生きて います。先生のご冥福を和祈り申しあげます。

(明治製菒生物科学研究所)

\section{二國先生のことごと}

福 場 博 保

あまりにも急に先生と和別れした現在, さて先生を偲 ぶことごとを書こうとすると，あらゆる想い出が走馬燈 のように脳裏をよぎり，なかなかまとまらない次第です。 先生は搌粉の研究を始める前にはいろいろと生物化学 全般の研究を持たれたようで，ことに大学を出られてか ら割合早い機会には，鈴木文助先生のご指導によるのか, 脂質関係のことも多く報告されて和られます。ことにホ スホリパーゼについてのご報告もあり，当時ご一緒に和 仕事をされた平尾菅雄さんと米糠中にこの酵素があって リゾレシチンが生ずることを明らかにされ，米を食べる と脚気になるのもこのリゾレシチンの影響ではないかと， 一時騒がれたとも伺った覚えがあります。

また, 南カリフォルニア大学に扔られた Deuel 博士 の “Lipids”という本の中にも，植物性不鹼化物である フィトステロールの体内吸収に関する記述の中に,

The only evidence that phytosterols can be absorbed is that of Nikuni (Z. Nikuni, J.Agr. Chem. Soc., Japan, 7, 827-838 (1931)) who experimented on mice, and that of von Gierke, who reported test on rabbits.

と記されています。

あるとき，この話を先生に申しあげたところ，ホスホ リパーゼの問題なども，今となってはもっとやって护 ばよかったと思っていると感想を述べて抢られたのを思 
い出します。

先生と同様, 澱粉と脂質の両方に足をか子てきた者と して，あまり知られていない脂質化学者としての一面も 先生は持ちで持ったことを書いてみぬした。

先生どうかこれからも私達の研究を見守り，ご指導願 いたいと思います。

(扣茶の水女子大学)

\section{二國先生亡鹿览島}

\section{本坊慶吉}

わが国の港粉の産地といえば，南は鹿児岛の甘諸䟝粉， 北は北海道の馬鉿薯潵粉である。

1953年（昭28）搌粉工業学会が設立され，翌年の1954 年に九州支部設立総会および講演会が鹿児島市で開催さ れました，私が二國先生と直接知りあったのはこの時期 からでした，その後，先生には機会あるごとに鹿児島を 訪間され，学会，講演会を通じて扮話をらかがい，また 日本激粉工㖝秼で講演をしていただいたことるありまし た.とくに潅粉粒の生成と外部環境については，春雨用 原料浿粉の物性との関係で一つのサゼスチョンを与员ら れました。

1957年 5 月に鹿览島大学で日本農芸化学会関西・西日 本支部合同大会が催され, 先生の「澱粉䊀の微細構造」 と題する特別講演があり，なた1960年に鹿児島大学で日 本農芸化学会西日本支部大会が開催されましたが，この 大会ではとくに澱粉の化学と利用に関するシンポジウム があり，先生からは「成熟期の環境が澱粉の性質に及ぼ 寸影響」と題する講演がなされました。

先生は大変山が扣好きであったことはご承知の通りで すが，1957年の支部大会終了後，筆者らは先生と一緒に 開聞岳（さつ束富士）と高千穂の峰（第島遇山の一つ） に登りました，高千穂の峰のとさは雨で霧が深く視界も 覀い天候でしたが，先生の希望むあって山頂まで登りま した。山頂では，山小屋の括じさんが，こんな亜い天候 で登山をするのはあなた方だけですと驚いていなした。 それはど先生は山が好きでした。

先生の在りし日を偲び，鹿児島での二，三の思い出を 記しました。

(日本澱粉工業株式会社)
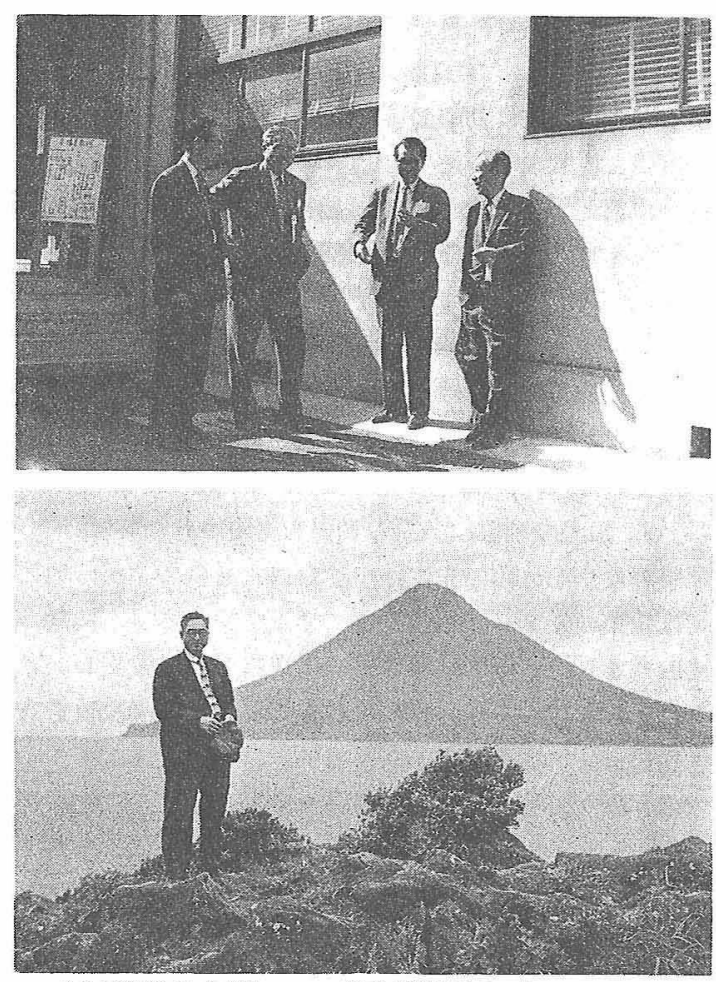

（上）鹿児島大学にて（下）開聞岳をバックルして

\section{二國先生亡江南短大}

\section{前田簅}

人の定めとは申乙まするのの，私たちの敬愛する二國 二郎先生が逝去されましたことは痛恨の極みであります。 大阪大学を停年退官された後の仕事として勤労女子青 年の教育に共感された先生が短大の設立に奔走され，腸 閉塞で見つかった結腸癌を乘越えて昭和45年4月20日に 入学式を終えた後, 江南団地のアパートに集まって乾杯 したときの先生の憙しそうな特顔は今であ忘れることが できません、その後, 教員ブームに乘って罗童教育学科 は順調に伸びましたが，家政学科は惨めなもので，昭和 48年に開設した食物栄着学専攻も定員を超えるよらにな ったのは二，三年前のことです。先生を初めとして，国 公立大学の経銿しかなかった私たらが最初に突き当った 壁が，学生を集めることと教えることの難しさでした。 国立大学の農芸化学科の学生ならば，「農芸化学で飯を 食らつもりならばこれくらいのことは自分で勉強しなさ 
い」と言って和けば自分でやってきますが，短大ではそ うはいきません。文字通り，手取り，足取りでなければ ならないのです.初めの頃, あまりにも再試の数が多か ったので，教方方が悪いと叱られました，そこで，「ご 自分で教えてみてください」と申しあげましたところ， しばらくして「相当なもんだ利」と一言，その後は教育 方法についてはすべてを任せてくださいました。

昭和54年 2 月に，スポンサーであった林紡績の倒産に より経済的援助を受けることができなくなって，学園は 独立採算の道を歩むことを余儀なくされ，先生が理事長 に就任されました，最初の校名の「林学園女子短期大 学」は, 短大の創設に多額の私財を寄附された林茂氏一 の感謝の念を込めて先生がつけられたものですが，地元 では企業のイメージが強過ぎて学生募集のネックになっ て和りました。昭和55年 4 月に現在の校名に変更し，さ らに家政学科を生活科学科改組して生活科学専攻を衣 と住のコースに分けてから，目的を持って入学してくる 学生が増光, 食物栄養学専攻とともにこれからの発展が 期待されて叔ります。

また，先生は建学の趣旨の中に，「教師と学生がとも に成長してゆく, そんな大学にしたい」とも書いて括ら れ, 教員の研究面でも細かい配慮をしてくださいました。 今までに 2 名が学位を取得し, 2 名が学位論文を作製中 であります，生前の先生に完成をご報告できなかったの は残念ですが，まだ数人が続いて和り，先生の播かれた 種がやがて大きく育ち花を咲かせる日も近いと確信して 抢ります。

(江南女子短期大学)

\section{二國先生の思い出}

\section{松田 和 雄}

私が二國先生にはじめて特目にかかったのは，先生が 米国 Purdue 大学への留学を終えて帰国された直後, 親 友の麻生教授を訪初て来仙された折と記憶している。し かし, 先生の叔人柄を強く印象づけられた最初の機会は, 先生が中心となって組織され，メンバーの一人として麻 生教授が参加された科学研究費総合研究の班会議に麻生 教授の代理として出席した1957年1月のことであった。 私は教授といら肩書をもった方々と話をする機会はたび たびあったが，先生ほど自由にうちとけてお弟子さん方 と話をされる方扮目にかかったことはなかった。
先生の暖かい特人柄にふれることのできた第 2 の機会 は，1963年 1 月麻生教授が亡くなられたときのことであ る. 新幹線のできていなかった時代，しかも大雪で交通 が混乱していた時期に先生はまっさきに大阪から駆けつ けてくださり，ご遺族を親身になって慰め，励まされ， 私達残された者の良い相談相手となってくださった。今 でも本当に有難いことと感謝している. 先生が終始学部 学生をもたない付置研究所の教授であられたのにもかか わらず，「二國グループ」と称される汪どの多くの信奉 者を身辺集められるよらになったのも，ひと洗生 の暖かい怙人柄に多くの人々が魅力を感じたからであろ う.

先生が健康を害して抢られるといらことをらかがった のは，昨年暮のことであった、難しいご病気とのことで あったが，15年前のあの大病から奇跡的に回復された先 生の強勒な生命力と幸運を思光ば，今回る必ず健康をと り戻されると信じていた．しかし，先生からいただいた 年賀状を読んだとき，私はなぜか，先生はご自分の病状 が回復の難しいことを知っていらっしゃるのではないか と不安な思いに駆られた。亡くなられる 2 週間ばかり前, 病床にある先生に有志の者から差しあげた㧤見舞に対し， 先生の奥様からよせられた和礼状の末尾正，とくに先生 の和言葉として「私は本当に果報者でした。有難うござ い亲した」と書かれてあるのを見て，先生はやはりご自 分の病状を自覚して拈られたのだとはっきり悟ることが できた、いかにも先生らしい別れの扔言葉であった。聞 くところによると，亡くなられる前の先生の苦痛はかな り激しいものだったにもかかわらず，周囲の方々に対す る深い愛情から汪とんど苦痛を訴兄られることなく最期 まで立派湛光られたということである. 先生の就人柄 がしのばれる思いである。

今は，もはや先生の温顔飞接することはできなくなっ てしまったが，つつしんで先生のご冥福を括祈り申しあ げます。

(東北大学農学部)

\section{二國先生を悼みて}

\section{三 崎旭}

数年前にも癌と闘って見事に征圧された二國先生です から，今回もきっと強䩓なご意志と体力で快復され，再 びあの温顔を私達に見せていただけると信じていただけ 
に，ご逝去の報せをうけて呆然としているのが偽らざる 心境です。，心定まら始ま满愛する先生の面影を浮か ベて和ります。

私は直接の先生の弟子ではありませんでしたが，いつ の間にか多糖の仕事の分野にのめり込んだ私にも，あの 大きい包容力で公私ともいろいろご指導してくださいま した。阪大醄酵の学生（27年卒）として初めて先生に教 えていただいたのは，実は激粉科学ではなく，「栄養化 学特論」といら名の講義でありました. ただ, 講義のか たわら, 澱粉研究の面白さ, 難しさをご自分の研究哲学 を軸にしていろいろ扔話になったのが，先の後私自身， 糖質の研究に足を踏み入机る端緒になったように思いま す.一つ，今でも強い印象として残っていることがあり ます。 vitamin $\mathrm{B}_{1}$ の話のときでしたが，米糠からの抗 脚気因子としての $\mathrm{B}_{1}$ の分離は鈴木梅太郎先生が C. Funk に先んじていたにもかかわらず，海外での発表が ほんの少し遅れたために外国研究者に名をなさしめたと いら扮話で，「君達もいい仕事は早く国際誌に発表しな ければならない」と強調されたのを覚えています。先生 は産研の教授時代に Whistler 教授のもとで電子顕微鏡 を用いた澱粉の研究をやって括られ，限られた期間と， かなりの技年で大変ご苦労されたと思いますが，先生の 特人柄注 Whistler 教授も魅せられて，その後刨頸の交 わりをされるようになったと聞いています。後年, 私も Fred Smith 教授の研究室に留学中に Whistler 教授を 訪祀たことがありましたが，Dr. Nikuni のことを大変 嬉しそうに話してくれたのを覚えています. Smith 教授 とい党ば, 私の留学中に一度宗教活動で東京に 1 か月滞 在したことがあります．私も同行してホテル・ニュージ ヤパンに泊って秥りましたが，わざわざ二國先生がホテ

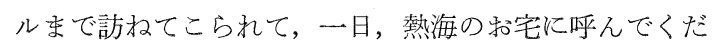
さったことがあります，最初に Smith 先生が風呂に入 ったのですが，米国のバス式に風呂の湯を全部抜いてし まったのです, 当時, 温泉の引き湯は一日一回とかで, 後で, 二國先生が困ったような笑い顔をされたのを今で 子懷しく思い出します，私は帰国後，しばらく製薬会社 の研究所に勤務していましたが，そのうち産研に移る機 会を得ました. 当時, 会社の許可が得られず難航してい たのを，所長であった二國先生が，あの叔人柄でうまく 話をつけ，円満に大学に移ることができ，現在の自分を 振返って有難く思っています。先生が産研をご退官後は あまり技目にかかる機会もなくなりましたが，先生のお 祝いの会, 学会, あるいは澱粉摡談会などで, 大きい身 体とあの独得のスマイルで，多くの招弟子さんに囲まれ
て嬉しそうな和顔をしていらっしゃるのを見て安らぎを 感じるのが常でした。

今, 私の書棚には, ページの黄ばんだ先生の「浿粉化 学」の名著が Haworth の “Sugars” の本と並んでいま す. 先に Smith 先生が消光, 今また二國先生が逝かれ, 私の糖の化学の手ほどきをしてくださった師はすべて消 えてゆき，淋しい限りです。ただ，先生のご冥福を祈る の久です。

(大阪市立大学生活科学部)

\section{「榮養學概論」について}

\section{三 輪 泰 造}

私は古い 1 冊の本を大事にしています。少し黄色に変 ったざら紙のB 5 判で, 表紙もそまつな本です。この本 は戦後間もない昭和 22 年の春頃, 本郷のある本屋で買っ たもので，著者は鈴木梅太郎，二國二郎の共著，書名は 「榮養學概論」, 発行は雄山閣, 昭和 22 年 4 月 1 日 5 版発 行，定価50円です.

その年の春, 上京して大学生活を始めた私は, 勉学の 志に燃光ていたとはいうものの, 毎日の食糧不足には全 くまいっていました，少ない配給の食糧でも何かよい工 夫はないるのかと考えているらちに，つい榮養學概 論」なる本を買ってしまったらしい。また当時は食糧難 から栄養失調なる言葉が流行していたので，この本を読 めば栄養失調にはならずにすむとでも思ったのかるしれ ません，用紙の統制で尃門書の発刊が少ない時代でした から，読書欲をかりたてて夢中になって読んだことを今

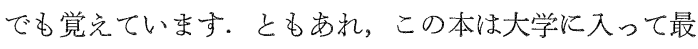
初に私が買った専門畫であり, 二國先生の叔名前を知っ た本でもあります、鈴木梅太郎先生の拈名前は，高等学 校(旧制)のとき，化学の先生からビタミンの大先生であ ることを聞いていました，それ故，共著の二國二郎先生 も偉い栄養学者だろらと思っていたわけです。

二國先生に初めて扔目にかかったのは昭和 29 年か 30 年 頃であったと思います、私どもの半田工場へ执いでにな り，たしか澱粉の構造についての拉話をされました。こ のとき，私は先生のご立派な和姿と明快なご講演にすっ かり感心してしまいました。そしてそれまでは，あの本 の著者だから, 二國二郎先生は栄養学の大家だと思い込 んでいたところ，実際に扔話を伺って，先生は澱粉の大 家でもあると知ったわけです，あの本から受けた先生の 
イメージはすっかり変りました。

大阪大学へ和伺いしたとき, 林学園の学長室へ和邪魔 したとき，熱海のご自宅へ参上したとき，その時々の先 生の报姿や和話しぶりが今でも思い出されます。和 和らかなご性格から，私は二國先生が大先生，大先輩で あることをつい忘れてしまって，話しこむようなことも ありました。よい先生を失いましたが，先生の思い出は いつまでもつきることがありません。

（日本食品化工株式会社）

\section{二國先生へ}

\section{山本武彦}

二國先生, 私が宮崎に出張中に伺ってびっくりしまし た、・称眠みでしょらが，俗界から先生に申しあげま के.

私が先生を拝見したのは，昭和 23 年秋だったと思い子 すが，先生が澱粉について九大医学部で講演されたとき でした，会場の後方で拝聴して括りましたが，容姿端麗， 白晳明眉な先生の講演に魅了されました，先生に親しく お目にかかったのは，私が大阪にまいりました望年の昭 和26年，農化木㺟会が生駒で行われたときです。先生の 研究室が当番教室として扔世話されていました．物のな いときでしたが，先生の趣向で抽選などの余興が催され， 大変なごやかに会が進み，私などは生意気にも若輩非才 を忘れて興じてしまいました。当時，先生はアミラーゼ の分類は Kuhn の方法で生成糖が $\alpha$ 型か $\beta$ 型かを基準 とすべきであるということを強調されていました，早速， 私達が枯草菌糖化型アミラーゼについて検討していただ いたところ， $\alpha$ 型であったので，実は内心はなはだ面白 くありませんでした，というのは，そのアミラーゼは既 知のアミラーゼと性質がずいぶん違っていたからです。 大阪市工研で行われた農化関西支部会で，枯草菌液化型 扣よび糖化型 $\alpha$ ーアミラーゼを $40^{\circ} \mathrm{C}$ に懸濁させた生澱粉 に作用させると，主生成糖は前者ではグルコース，マル トース，マルトトリオースが，後者ではグルコース，マ ルトースが主で，可溶性嘱粉基質の場合と著しく異なる （追試の必要あり）ことについて報告したところ，先生か ら何かと質問されました。

澱粉の構造について執心されて，先生が拈そろしく溲 身となって州国されたのにびっくりしました。しかし，
いとも短期間に以前にも増した健康状態となられ，小さ なカブト虫型自動車を運転されていました。それはよい として，同乗せよといわれ，大阪市内を通って梅田まで 送っていただきましたときは肝を冷やしました。

日本生化学会会頭を和やりになった頃から，柰すす 円満さを感じさせられました。しかし，学会で質問され るとさは，芒洋とした中にも厳然たるものを感じさせら れました，澱粉㴧談会などでの思い出はつきません，今 にして思壳ば，もっともっと先生から習って和くべきで した. 手前の勝手ですが残念です。でも，先生が私を 少なくとも半人前ぐらいの研究者として対応いただき ましたことに深く感謝申しあげます。先生，なにとぞ安 らかに永く莇眠りください，合掌

(大阪市立大学理学部)

\section{二國先生の想い出}

\section{頼 富 憲三郎}

戦後しばらくたって, 飛行機屋から飴屋に転進して洪 粉の加工に従事するようになった頃, 雑誌科学朝日で二 國先生のアルファ米の記事を拝読しました. その頃の科 学朝日は用紙がざら紙の粗末なものでありましたが，そ の記事で澱粉の摩訶不思議な性質と, 大阪大学に澱粉の 大家二國先生が括られることをはじめて知ることができ ました。

はじめて先生に扣目にかかれましたのは，例年夏に開 かれた大阪の澱粉糖技術研究会で澌粉の構造についてご 講演を和願いしたときです。そのときの印象は，何と話 の上手な先生であろらか, 先生の講義を受ける学生は幸

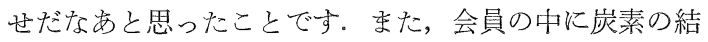
合角度に詳しい人が招り，難しい質問をしましたが，大 変明解に和答えになられました。

昭和28年だと記憶しますが，二國先生が同級の麻生先 生と当時千葉にありました醱酵研究所に来られて, やは り同級の務台先生のご案内で参松工業千葉工場に和見え になりました，先生が米国留学にあたり，日本の澱粉糖 の工場の現状も知って括くための工場見学が目的でした。 当時の先生は, 麻生先生の有名な白髪に比べて, 真黒な 長い髪と大きな体格が大变若々しく印象に残って和り, 当時米国に対してコンプレックスを持っていた私も先生 なら米国に行かれても堂々とやってこられると意を強く 
した次第です，その当時，私は酒造用の糖として粉末水 飴の前身となった精製結晶デキストリンを測粉の低 DE 分解物からつくることをはじめて物りましたが，それは 球形であって結晶と呼んでよいかどうか迷って物りまし た、結晶とは軸と面があるものと解釈して特りましたか

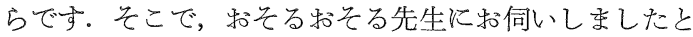
ころ，先生から明快にそれは球形でる結晶と呼んでよろ しいとの拈答えをいただき，勇気百倍して特許にも結晶 デキストリンと表現することができました。

その後澱粉学会やSRT にて度々敌目にかかる上うに なり，先生の大きな包容力と扬人柄に，私自身梳も之上 り学会に関係する人すべてが先生に拈目にかかれるのを 楽しみに集委り，先生を中心にして勉強し，酒を领み， そして先生のすべてを通して，人間の生き方まで学ら゙こ とができました，そして先生の弟子の一員にまで加光 ていただくよらになり，大変有難く幸せに思って和りま g.

先生がヒマラヤ旅行から帰られた䪸の学会の役員留親 会で，やはり無類の招酒好きの小林畺一さえが血圧降下 剤を叔酒で飲みながら先生と薬の話をされて括りました とき，先生思いの中村道德先生が血圧降下剂の害を諪々 と説かれて, 先生に「酒は飲んでも薬だけは止めるよう」 進言されましたら，先生は「酒る飲むが薬る飲むよ」と 抒っしゃられ，いかにも先生らしい怙答にあいた口が示 さがらなかったことを思い出します。あの世に必必ず酒 があることを信じつつ，先生のご冥福を特祈りいたしま す.

（元 参松工業株式会社）

\section{二國先生亡私}

\section{吉 町 晃 -}

昭和59年は，私にとって忘れられない年になってしま った。先に北海道支部長の大塚先生を10月15日に，前士 幌町農協組合長太田寬一氏を11月13日に失い，そして11 月21日には二國先生の訃報に接することとなったからで 嵓る. 前田先生からそ机となくご容態を伺っていて覚悟 はしていたつもりでも，その淋しさは言葉では言い表す ことができない。

先生の扮名前を初めて知ったのは，昭和27年，私の卒 論実験の昔にさかのぼる、テーマが澱粉に関するもので あったため，名著「澱粉化学」を最良の参考書としたか
らである。

その中に，テーマに直接は関係なかったが，私の恩師 故 中村幸彦先生の出された, 漴粉中に $\alpha-1,3$ 結合があ るとする結果に対し，二國先生が疑問符をつけられた部 分があった．弟子としては親分の肩を持ちたいのは当然。 いずれ追試をしてと思いつつ果たせなかったが，先生の 特名前はこのときから強烈飞，私の印象に残ることにな った.

初めて扮会いできたのは，31年，伊東市西小学校で催 された澱粉学会（当時は研究発表会）であった，先生は， 「わが国及びアメリカに拈ける最近の澱粉の研究につい て」の演題で講演され, 電顕を用いたアメリカでのご研 究成果の報告で，聴衆を魅了された。

終了後, 今考光机ばいかに前述した気負いが㭊ったに せよ，まことに赤面るのだが，学校出たてのぺエペエが， 本でしか存じあげなかった雲上人の大先生に，厚かまし くも名乗りをあげてしまった．先生は，「貴方は弓師(東 大農化時代，弓をしていた父のあだな，42歳で歿）の息 子さんか」といらことから，私の知らなかった親父の一 面を聞かされたり，父と同期の郷田さん，あるいは尾崎 先生をご紹介いただけるハプニングに発展した。

先生の温かい怙人柄化接して以降, 先生のファンとい うより，直接の弟子でないにもかかわらず，気持のう党 では二國一門の末席を名乗らせていただくきっかけとな った。

私の恥と先生の招人柄（研究熱心さ?) 飞まつわる話 はもら一つある. 36年, 福岡での農芸化学会シンポジゥ ム「澱粉と矢の利用」の席上, 演者への質問の中で，馬 鈴薯激粉の大小粒子の粘度特性に関して私の研究結果を 説明し過ぎ，座長（ぞなただったか）にたしなめられた ことがある。昼休み，いささか意気消沈していた私に， 先生は内容の詳細な説明を求められ，励ましてくださっ たが，つい昨日の出来事のように思い出される.

先生の箃しさについて一つふ扎て和くならば，40年， 赤坂公会堂での想い出がある. 先生の拈弟子のKさんが 「澱粉の小量粘度計の試作」について報告された際, 持 ら時間をはみ出してしまった．最前列に座っておられた 先生は，「君，時間だうう。やめ給光」と一言，大量の 試料を必要とする従来のアミログラフに代わるものとし て，大きな興味を持っていた私には，尻切れトンボの結 末が正直言って残念だった、だが半面，「与兄られた時 間内できちんとまとめるのが研究者の能力」とさとされ たのだろうと，身の引き締まる思いがしたことであっ た。 
先生の想い出を語ればきりがない。日本の SRT の創 設に関してもふれたかったが，すでに与兄られだ紙数は オーバー、なた先生に此られそらな気がする。ただ最後 に, 現在らるさく言和机ている産学官共同研究に関して, 先生の先見の明がよく現れているため，「アメリカの淈
粉円卓会議」（澱粉工誌，通巻11号，38４0（1956））の 読み返しを皆様に打勧めして和きたい。

先生，本当に特世話になりました。いずれ天界での SRT に参加させていただきます。

（北海道立工業試験場） 